191

Received: February 10, 2015

Accepted: May 30, 2015
Macedonian Journal of Animal Science, Vol. 5, No. 1, pp. 5-9 (2015)

In print: ISSN $1857-6907$

On line: ISSN $1857-7709$

UDC: $637.12{ }^{\prime} 637.04$

$637.12^{\prime} 637.055$

Original scientific paper

\title{
THE INFLUENCE OF LACTATION NUMBER AND SEASON ON YIELD, CHEMICAL AND MICROBIOLOGICAL STATUS OF SHEEP MILK
}

\author{
Zoran Z. Ilić ${ }^{1}$, Violeta Caro Petrović ${ }^{2}$, Milan P. Petrović ${ }^{2}$, Radojica Djoković ${ }^{3}$, \\ Vladimir Kurčubić ${ }^{3}$, Bojana Ristanović ${ }^{1}$, Nikola Pacinovski ${ }^{4}$ \\ ${ }^{1}$ Faculty of Agriculture, Kopaonička bb, 38219 Lešak, Serbia \\ ${ }^{2}$ Institute for Animal Husbandry, Autoput 16, 11080 Belgrade-Zemun, Serbia \\ ${ }^{3}$ Faculty of Agronomy, Cara Dušana 34, 32000 Čačak, Serbia \\ 4 "Ss. Cyril and Methodius" University in Skopje, Institute of Animal Science, \\ Blvd. Ilinden 92A, 1000 Skopje, Republic of Macedonia \\ zoran.ilic@pr.ac.rs
}

\begin{abstract}
In the investigation utilized 800 head of Pirot improved sheep during two lactation numbers (I and II) and two lactation seasons: I - winter, and II - summer. Investigated the influence of some factors on milk yield, fat content, protein content, $\mathrm{pH}$ value, SCC (somatic cell count) and CFU (total number of microorganismis). Control of milk yield was carried out by the AC method (ICAR, 2005). It was ascertained a significant impact $(\mathrm{P}<0.05$ and $(\mathrm{P}<$ 0.01) of lactation number on traits of milk, except for content of fat, somatic cell counts and total bacterial count. The amount of milk in the second year was higher by $5.25 \mathrm{~kg}$ compared to the milk yield of sheep in the first year. Milk yield was higher in the second season for $6.75 \mathrm{~kg}$, which was statistically significant $(\mathrm{P}<0.05)$. The fat content was higher in the first season for $0.29 \%$, which was also statistically significant $(\mathrm{P}<0.05)$. Milk protein content was higher in first lactation for $0.30 \%$, and difference was statistically significant $(\mathrm{P}<0.01)$; $\mathrm{pH}$ value in milk was significantly higher in the second lactation $(\mathrm{P}<0.01)$. The number of lactation had no significant effect on somatic cells count in milk $(\mathrm{P}>0.05)$. Total number of microorganisms (CFU) also did not depend on the number of lactation $(\mathrm{P}>0.05)$. Sheep in the second season had a higher milk yield for $6.75 \mathrm{~kg}(\mathrm{P}<0.05)$ and higher total number of microorganisms $(\mathrm{P}<0.01)$. Somatic cells in milk was also higher during the season II $(\mathrm{P}<0.01)$.
\end{abstract}

Key words: sheep; milk yield; lactation number; season; chemical and microbiological status

\section{ВЛИЈАНИЕ НА БРОЈОТ НА ЛАКТАЦИЈАТА И НА СЕЗОНАТА ВРЗ КОЛИЧИНАТА И ХЕМИСКИОТ И МИКРОБИОЛОШКИОТ СТАТУС НА ОВЧОТО МЛЕКО}

Во испитување се користени вкупно 800 грла од пиротската унапредена овца, во текот на две лактации (прва и втора) и две лактациски сезони (I - зимска и II - летна). Испитувано е влијанието на некои фактори врз производството на млеко, содржината на млечна маст, содржината на протеини, $\mathrm{pH}$-вредноста, бројот на соматски клетки (SCC) и вкупниот број на микроорганизми (CFU). Контролата на производството на млеко е извршена со помош на AC-методот (ICAR, 2005). Утврдено е значајно влијание $(\mathrm{P}<0,05)$ и $(\mathrm{P}<0,01)$ на бројот на лактацијата врз својствата на млекото, со исклучок на содржината на млечна маст, бројот на соматските клетки и вкупниот број на микроорганизми. Количината на млеко во втората година беше поголема за $5,25 \mathrm{~kg}$ во споредба со количината на произведено млеко по овца во првата година. Производството на млеко беше повисоко во втората сезона за $6,75 \mathrm{~kg}$, што е статистичко значајно $(\mathrm{P}<0,05)$. Содржината на млечна маст беше повисока во првата сезона за $0,29 \%$, што е исто така статистички значајно $(\mathrm{P}<0,05)$. Содржината на протеини беше повисока во првата лактација за $0,30 \%$ и разликата беше статистички значајна $(\mathrm{P}<0,01)$. Вредноста на $\mathrm{pH}$ на млекото беше значајно повисока во втората лактација (P $<0,01)$. Бројот на лактацијата немаше значајно влијание врз содржината на соматските клетки во млекото (P $>0,05)$. Вкупниот број на микроорганизми (CFU) исто така не зависеше од бројот на лактацијата $(\mathrm{P}>0,05)$. Овците во втората лактација имаа поголемо производство на млеко за $6,75 \mathrm{~kg}(\mathrm{P}<0,05)$ и поголем вкупен број на микроорганизми $(\mathrm{P}<0,01)$. Бројот на соматските клетки во млекото беше исто така поголем за време на втората (летна) сезона $(\mathrm{P}<0,01)$.

Клучни зборови: овци; производство на млеко; број на лактација; сезона; хемиски и микробиолошки статус 


\section{INTRODUCTION}

The quantity and quality of sheep milk are the backbone of all research and development projects aimed at creating preconditions for the production of highly respected cheeses (Gasser, 2000; Bendall, 2001; Kukovics and Javor, 2001; Di Cagno et al., 2003; Gabina, 2006; Petrović et al., 2006; D'Amico and Donnelly, 2010).

Estimates of the amount of milk produced by lactating ewes provide information for the implementation of optimum management and feeding strategies for ewes and their lambs (Cardellino and Benson, 2002). Milk yield and quality of sheep varies depending on genetic as well as the impact of numerous environmental factors (Petrović et al., 2000). Herd, year, season significantly affected all milk traits as basically reported in all studies dealing with environmental effects in milk producing livestock (Fuerst-Waltl et al., 2005; Ortiz et al., 2012).

Yield and quality of sheep milk is different depending on growing conditions (Barillet et al., 2001; Astruc et al., 2002; Jurado et al., 2006). Microbiological quality of raw milk is assessed in large extend by total bacteria count and somatic cell count, and these parameters are routinely measured and compared. Microbial analysis and somatic cell count have been used to diagnose mastitis in ewes (Oravcová et al., 2005). Pinelli et al. (2001), suggest that for milk yield of sheep is important design and implementation of genetic improvement program. The maximum milk yield of sheep can be achieved on the third lactation and is held up to six years of age. The highest daily milk yield of sheep is carried out on 20 to 30 days of lactation. The number of offspring per sheep affects milk yield. Influence of environmental factors on milk yield at quality was the subject for research of other authors (Barillet et al., 2001; Thomas et al., 2001; Reiad et al., 2010). Objective of this paper was to investigate the impact of lactation number and season on the yield and milk quality.

\section{MATERIAL AND METHODS}

As an integral part of the project, the research was conducted in the Stara Planina mountain. The study included 800 head of Pirot improved sheep in the first (I) and second (II) lactation (400 sheep per lactation). Depending on the lactation season, the ewes were divided into two groups $(200+$ 200). Season I (winter) and season II (summer).
Due to changes of the seasons, the diet of sheep varied in lactation. During the first (I) season, sheep were kept in the farm building and fed hay plus concentrate. During the second (II) season, dairy sheep stayed on natural pastures, where they grazed mountain grass, without any additives. Control of milk yield was carried out by the $\mathrm{AC}$ method (ICAR, 2005). For the analysis of milk, 200 samples were taken for each trait. Daily quantity of milk produced was determined by measuring the bulk volume ( $\mathrm{ml})$.

Milk fat content and protein was determined by infrared spectrometry, $\mathrm{pH}$ values of milk at Hanna Instruments $\mathrm{pH}$ meter 301 , somatic cells (SCC) of an electronic Coulter counter - Couter D, a total number of microorganisms (CFU) by flow cytometry. To obtain a normal distribution, the number of somatic cells and the number of microorganisms are in logarithms $\left(\log _{10}\right)$. All milk analyzes were carried out according to the Ordinance on the quality of raw milk ("Off. Gazette RS", no. 21/2009).

Statistical analysis was performed through the linear procedure using statistical software package SPSS 20.0 (2012). using the next model:

$$
Y_{i j k}=\mu+G_{\mathrm{i}}+S_{j}+b_{1}\left(\mathrm{x}-x_{1}\right)+e_{i j k},
$$

where,

$Y_{i j k}$ - value of traits on the $k$-th animal in the $j$-th season and $i$-th lactation number,

$\mu$-overall population mean,

$G_{i}$ - effect of $i$-th lactation number,

$S_{j}$ - effect of $j$-th season,

$b_{1}$ - linear regression coefficient of age of dams at first insemination,

$$
e_{i j k} \text {-random error. }
$$

\section{RESULTS AND DISCUSSION}

On the Table 1 can be seen that milk yield of examined sheep varied, depending on the number of lactation. Namely, the amount of milk of sheep in the second lactation was higher by $5.25 \mathrm{~kg}$ compared to the milk yield of sheep in the first lactation. This difference was statistically significant $(\mathrm{P}<0.05)$. It is interesting that the fat content in milk was higher for $0.09 \%$ in the second lactation, however difference was not statistically significant $(\mathrm{P}>0.05)$. Similar results of milk yield in Pirot sheep cited in their research Petrović and Caro Petrović (2005). According to Mekić et al. (2005) milk yield of Svrlig breed of sheep was $74.1 \mathrm{~kg}$, content of fat $6.54 \%$. Moioli and Pilla 
(1994) stated about the effect of environment on milk yield. Barillet et al. (2001) reported about flock-year effect of milk production in Lacaune breed. Fuerst-Waltl et al. (2005) stated that lactation number had a significant effect on all traits except fat percentage. By Cardellino and Benson (2002) effects, age affected milk production in sheep. Eftimova et al. (2009) stated that the average milking capacity in the Ovčepole Pramenka, during lactation was $76 \mathrm{~kg}$, average milk fat 7.92 $\%$. Pacinovski et al. (2007), in their research in East Friesian sheep came to the conclusion that content of milk fat in the milk was in average $5.64 \%$. The mentioned authors further add that almost all the examined factors (year, lactation, number of milk control) highly influenced $(\mathrm{P}<$ 0.001 ) the daily milk production and fat content. Table 1 shows that milk protein content was higher in the first lactation for $0.30 \%$, and difference was statistically significant $(\mathrm{P}<0.01)$. $\mathrm{pH}$ value in milk was significantly higher in the second lactation $(\mathrm{P}$ $<0.01$ ). Sevi et al. (2004) found a significant effect of lactation on all milk components under their study; also Konečná et al. (2011) reported a significant effect of the lactation parity on contents of total solids, fat and total protein.

Table 1

Effect of lactation number on yield, chemical and microbiological status of milk

\begin{tabular}{|c|c|c|c|c|}
\hline \multirow[t]{2}{*}{ Traits } & \multirow[t]{2}{*}{$\mu$} & \multicolumn{2}{|c|}{ Mean \pm S.E } & \multirow{2}{*}{$\mathrm{P}$ value } \\
\hline & & Lactation I & Lactation II & \\
\hline Milk yield, kg & 63.92 & $61.29 \pm 1.95$ & $66.54 \pm 1.79$ & $<0.05$ \\
\hline Content of fat, $\%$ & 6.44 & $6.40 \pm 0.10$ & $6.49 \pm 0.09$ & $>0.05$ \\
\hline Protein, \% & 5.45 & $5.60 \pm 0.29$ & $5.30 \pm 0.23$ & $<0,01$ \\
\hline $\mathrm{pH}$ value & 6.63 & $6,60 \pm 0,10$ & $6,66 \pm 0,12$ & $<0,01$ \\
\hline $\log _{10} \mathrm{SCC}$ & 5.48 & $5,46 \pm 0,05$ & $5,50 \pm 0,06$ & $>0.05$ \\
\hline $\log _{10} \mathrm{CFU}$ & 4.91 & $4,90 \pm 0,11$ & $4,93 \pm 0,14$ & $>0.05$ \\
\hline
\end{tabular}

Number of somatic cells in sheep milk is highly variable and influenced by many factors. Breed, stage and lactation, estrus, litter size, and daily, monthly and seasonal variations contribute to significant changes in somatic cells (Pešić Mikulec et al., 2005; Paape et al., 2007). Our results showed that the number of lactation had no significant effect on somatic cells in milk $(\mathrm{P}>$ $0.05)$. Results of this research are consistent with Othmane et al, (2002), who have not found a significant effect of order, or stage of lactation on somatic cells in milk. Rupp et al. (2003) did not find differences in the number of somatic cells between the first and the second lactation, which was also found in this study. Total number of microorganisms (CFU), as shown in Table 1, also did not depend on the number of lactation. The current difference was not statistically significant $(\mathrm{P}>0.05)$.

Influence of lactation season on milk traits can be seen in Table 2 .

On Table 2 showed that the sheep in the second season had a higher milk yield for $6.75 \mathrm{~kg}$ which was statistically significant $(\mathrm{P}<0.05)$. The difference in milk production between the studied season can be interpreted as a factor of feeding.

\section{Table 2}

\section{Effect of season on milk yield, chemical and microbiological status of milk}

\begin{tabular}{|c|c|c|c|c|}
\hline \multirow[t]{2}{*}{ Traits } & \multirow[t]{2}{*}{$\mu$} & \multicolumn{2}{|c|}{ Mean \pm S.E. } & \multirow[t]{2}{*}{ P-value } \\
\hline & & Season I & Season II & \\
\hline Milk yield, kg & 63.92 & $60.54 \pm 1.96$ & $67.29 \pm 1.79$ & $<0.05$ \\
\hline Content of fat, $\%$ & 6.44 & $6.59 \pm 0.10$ & $6.30 \pm 0.09$ & $<0.05$ \\
\hline Protein, \% & 5.48 & $5.31 \pm 0.22$ & $5.63 \pm 0.31$ & $<0,01$ \\
\hline $\mathrm{pH}$ value & 6.65 & $6,62 \pm 0,11$ & $6,68 \pm 0,13$ & $<0,01$ \\
\hline $\log _{10} \mathrm{SCC}$ & 5.46 & $5,39 \pm 0,03$ & $5,69 \pm 0,06$ & $<0,01$ \\
\hline $\log _{10} \mathrm{CFU}$ & 4.89 & $4,84 \pm 0,11$ & $5.08 \pm 0,14$ & $<0,01$ \\
\hline
\end{tabular}

Lactation of sheep in the second season was during the summer months, when the pasture has a lot of young, juicy grass, as opposed to the winter season when the sheep were feeding hay. Season shows effect on protein content, which was higher in second season and difference was statistically significant $(\mathrm{P}<0.01)$. The $\mathrm{pH}$ value in milk was also significantly higher in the second season $(\mathrm{P}<$ $0.01)$. Season of lactation had a significant effect $(\mathrm{P}<0.01)$ on total number of microorganisms (CFU) which is consistent with results published by Micari et al. (2002), Talevski et al. (2009). A similar trend in ours was reported by Sevi et al. (2004) and Malá et al. (2010). Higher value of this parameter in the second season was expected, because the more air temperature during summer creates better conditions for the development of microflora. Similarly microorganisms, somatic cells in milk was also higher during the season II $(\mathrm{P}<0.01)$. Milk composition and factors affecting 
their variation throughout the lactation and relationships between milk yield and milk composition were studied by other authors. A positive influence of season during spring months with rich pastures and a negative influence of summer months with poor and scarce pastures on Valle del Belice dairy ewes, was reported by Cappio-Borlino et al. (1997). Oravcová et al. (2007) stated that fat content, analyses showed a highly significant $(\mathrm{P}<$ $0.01)$ effect of flock-test day and a highly significant $(\mathrm{P}<0.01)$ or significant $(\mathrm{P}<0.05)$ effect of the month of lambing in Tsigai and Improved Valachianwith sheep. The effect of the seasonality of Lacha sheep's milk production on the milk-fat composition was studied by Perea et al. (2000). The results showed that the characteristics of the milk-fat components, changed with the time of the year. The June milk had a higher content of unsaturated and long-chain fatty acids and triglycerides. The April and February milks were very similar, with a higher content of saturated and short-chain fatty acids and triglycerides. The differences in animal feeding during different seasons were important factor affecting milk composition.

\section{CONCLUSIONS}

On the basis of processed research and results presented, we can draw the following conclusions:

Number of lactation has an effect on more traits of milk, except for content of fat, somatic cell counts and total microorganisms count. However, our research shows that the season has an effect on all traits of milk. In the literature we have cited, there are similarities and differences with our results. It is therefore necessary to make constant examinations in different breeds and farm conditions, to obtain high-quality milk as a raw material for processing a quality cheeses.

Acknowledgments: Research was financially supported by the Ministry of Education, Science and Technological Development, Republic of Serbia, with in the projects TR 31001 and TR 31053.

\section{REFERENCES}

[1] Astruc, J. M., Barillet, F., Barbat, A., Clément, V., Boichard D.: Genetic evaluation of dairy sheep in France. In: Proceedings of the Seventh World Congress on Genetics Applied to Livestock Production, Montpellier, France, CDROM Communication No. 01-45 (2002).

[2] Barillet, F., Marie, C., Jacquin, M., Lagriffoul, G., Astruc, J. M.: The French Lacaune dairy sheep breed: use in
France and abroad in the last 40 years. Livest. Prod. Sci. 71, 17-29 (2001).

[3] Bendall, J. G.: Aroma compounds of fresh milk from New Zealand cows fed different diets. J. Agric.Food. Chem. 49, 25-4832 (2001).

[4] Cappio-Borlino, A., Portolano, B., Todaro, M., Macciotta, N. P. P., Giaccone, P., Pulina G.: Lactation curves of Valle del Belice dairy ewes for yields of milk, fat and protein estimated with test day models. J. Dairy Sci. 80, 3023-3029 (1997).

[5[ Cardellino, R. A., Benson M. E.: Lactation curves of commercial ewes rearing lambs. J. Anim. Sci. 80, 23-27 (2002).

[6] D'Amico, D. J., Donnelly, C. W.: Microbiological quality of raw milk used for small-scale artisan cheese production in Vermont: effect of farm characteristics and practices. J Dairy Sci. 93. 134-47 (2010).

[7] Di Cagno, R., Banks, J., Sheehan, L., Fox, P. F., Brechany, E. Y., Corsetti, A., Gobbetti M.: Comparison of the microbiological, compositional, biochemical, volatile profile and sensory characteristics of three Italian PDO ewes' milk cheeses. Int. Dairy J. 13, 961-972 (2003).

[8] Eftimova, E., Pacinovski, N., Lambevska-Domazetova, V.: Comparative production features of Awassi and Ovčepole Pramenka cross-breeds in the Republic of Macedonia. Biotechnology in Animal Husbandry, 25. 901906 (2009).

[9] Fuerst Waltl, B., Baumung, R., Sölkner, J.: Effect of birth type on milk production traits in East Friesian ewes. 56th Annual Meeting of the European Association for Animal Production (EAAP), Uppsala, June 5-8 (2005).

[10] Gabina, D.: The future of sheep and goat production in Europe: prospects within the framework of new support regimes and market conditions. Small Ruminant Research, 62, 159-165 (2006).

[11] Gasser, H.: Sheep Cheese-Making and Marketing. Proceedings of the Great Lakes Dairy Sheep Symposium, November 2-4, Guelph, Ontario, Canada, 155-158 (2000).

[12] ICAR: International agreement of recording practices. Available at: http://www.icar.org (2005).

[13] Jurado, J. J., Serrano, M., Pérez-Guzmán, M. D.: Analysis of the genetic progress obtained in the selection program in Manchega sheep breed. ITEA (Información Técnica Económica Agraria) 102, 41-54 (2006).

[14] Konečnà, L., Kuchitík, J., Kràličková, S., Pokorná, M.: Effect of lactation order on milk yield and elemental composition of organic sheep milk ewes, crossbred Lacaune breed and Východofríská sheep. Farmer cheese production and fermented milk products (in Czech), 8, 40-41 (2011).

[15] Kukovics, S., Javor, A.: Prospects for small ruminant production and consumption in Eastern Europe, Proceedings of the 52nd Annual Meeting of the EAAP, vol. 7, Budapest, Hungary, 26-29 August, p. 251 (2001).

[16] Malá, G., Švejcarová, M., Knížek, J., Peroutková, J: Je mikrobiologická kvalita ovčího mléka ovlivněna způsobem dojení. Sbornik referátů ze semináře farmářská výroba sýru a kysaných mléčných výrobkü, VII, MENDELU v Brně, 37-38 (2010)

[17] Mekić, C., Petrović, M. P., Trifunović, G., Zujović, M., Perišić, P.: Milk production of Svrljiska stock of domestic 
tuft sheep. Biotechnology in Animal Husbandry, 21, 8588 (2005).

[18] Mikulec, D., L. Stojanović, V. Katić: Ecological parametres and quality of raw milk in different geographical location in Serbia. Journal of Mountain Agriculture on the Balkans. 8, 135-146 (2005).

[19] Micari, P., Caridi, A., Colacino, T., Caparra, P., Cufar, A.: Physicochemical, microbiological and coagulating properties of ewe's milk produces on the Calabrian Mount Poro Plateau. International Journal of Dairy Technology, 55, 204-210 (2002).

[20] Moioli, B. M., Pilla, A. M.: Genetic evaluation of dairy sheep with an animal model for annual or partial lactation production. J. Dairy Sci., 77, 609-615 (1994).

[21] Oravcová, M., Groeneveld, E., Kovac, M., Peškovičová, D., Margetin, M.: Estimation of genetic and environmental parameters of milk production traits in Slovak purebred sheep using test-day model. Small Rumin. Res., 56, 113-120 (2005).

[22] Oravcová, M., Margetin, M., Peškovičová, D., Daňo, J., Milerski, M.: Factors affecting ewe's milk fat and protein content and relationships between milk yield and milk components. Czech. J. Anim. Sci., 52, 189-198 (2007).

[23] Ortiz Rodriguez, R., J. J. Valdez Alarcon, B. GomezRamos, J. López-Medina, M. P. Chávez Moctezuma, P. A. Garcia Saucedo, R. E. Perez-Sanchez,: Yield and microbiological quality of raw milk and fresh cheese obtained from Holstein cows receiving a diet supplemented with nopal (Opuntia ficus-indica). African Journal of Microbiology Research, 6, 3409-3414 (2012).

[24] Othmane, M. H., De la Fuente, L. F., Carriedo, J. A., San Primitivo, F.: Heritability and genetic correlations of test day milk yield and composition, individual laboratory cheese yield, and somatic cell count for dairy ewes. Journal of Dairy Science, 85, 2692-2698 (2002).

[25] Pacinovski N., Dimov, G., Eftimova, E.: Some production traits of the new imported East-Friesian sheep in Macedonia. Biotechnology in Animal Husbandry 23, 113121 (2007).

[26] Paape, M. J., Wiggans, G. R., Bannerman, D. D., Thomas, D. L., Sanders, A. H., Contreras, A., Moroni, P.,
Miller, R. H.: Monitoring goat and sheep milk somatic cell counts. Small Ruminant Res. 68:114-125, (2007).

[27] Pešić Mikulec D., Petrović, M. P., Ružić, D.: Research the quality of row milk for production pirot katchaval. 8 . International symposium - Modern Trends in Livestock Production, Belgrade. Biotechnology in Animal Husbandry, 5-6, book 2:43-48 (2005).

[28] Petrović P. M.: Genetic and improvement of sheep. Sci. Book, Belgrade, pp. 365 (2000).

[29] Petrović P. M., Caro Petrović, V.: Sheperding and sheep production in the region of mountain Stara Planina Serbia. $3^{\text {rd }}$ World Congress of Shepherds. Spain, Sept. 21-24. Book of Communications, 27-30 (2005).

[30] Petrović P. M., Ružić Muslić, D., Žujović, M.: Effect of systematical factors on yield and quality of sheep milk. Biotechnology in Animal Husbandry 22, 34-39 (2006).

[31] Pinelli F., Oltenacu, P. A., Iannolino, G., Grosu, H., D’Amico, A., Scimonelli, M., Genna, G., Calagna, G., Ferrantelli, V.: Design and implementation of a genetic improvement program for Comisana dairy sheep in Sicily. Proceedings of the Great Lakes Dairy Sheep Symposium, November 2-4, Guelph, Ontario, Canada, 137-150 (2000).

[32] Rupp R., Lagriffoul, G., Astruc, J. M., Barillet, F.: Genetic Parameters for Milk Somatic Cell Scores and Relationships with Production Traits in French Lacaune Dairy Sheep. Journal of Dairy Science, 86, 1476-1481 (2003).

[33] Sevi A., Albenzio, M., Marino, R., Santillo, A., Muscio, A.: Effect of lambing season and stage of lactation on ewe milk quality. Small Ruminant Research, 51, 251-259 (2004).

[34] SPSS for Windows, Rel. 20.0, 2012. Chicago: SPSS Inc.

[35] Talevski, G., Čobanova-Vasilevska, R., Srbinovska, S., Sireta, Z.: Quality of the sheep milk as a raw material in dairy industry of Macedonia. Biotechnology in Animal Husbandry, 25, 971-977 (2009).

[36] Thomas D. L., Berger, Y. M., McKusick, B. C.: Effects of breed, management system, and nutrition on milk yield and milk composition of dairy sheep. J. Anim. Sci., 79 (E. Suppl.): E16-E20 (2001). 